\title{
Characterization of elemental sulfur in chalcopyrite leach residues using simultaneous
} thermal analysis

Lv, Cuicui; Wu, Hao; Lin, Weigang; Illerup, Jytte Boll; Karcz, Adam Paul; Ye, Shufeng; Damø, Anne Juul

Published in:

Hydrometallurgy

Link to article, DOI:

10.1016/j.hydromet.2019.05.020

Publication date:

2019

Document Version

Peer reviewed version

Link back to DTU Orbit

Citation (APA):

Lv, C., Wu, H., Lin, W., Illerup, J. B., Karcz, A. P., Ye, S., \& Damø, A. J. (2019). Characterization of elemental sulfur in chalcopyrite leach residues using simultaneous thermal analysis. Hydrometallurgy, 188, 22-30. https://doi.org/10.1016/j.hydromet.2019.05.020

\section{General rights}

Copyright and moral rights for the publications made accessible in the public portal are retained by the authors and/or other copyright owners and it is a condition of accessing publications that users recognise and abide by the legal requirements associated with these rights.

- Users may download and print one copy of any publication from the public portal for the purpose of private study or research.

- You may not further distribute the material or use it for any profit-making activity or commercial gain

- You may freely distribute the URL identifying the publication in the public portal 


\section{Characterization of elemental sulfur in chalcopyrite leach residues using simultaneous thermal analysis}

Cuicui Lv ${ }^{\mathrm{a}, \mathrm{b}, \mathrm{c}}$, Hao $\mathrm{Wu}^{\mathrm{b}^{*}}$, Weigang Lin ${ }^{\mathrm{b}, \mathrm{c}}$, Jytte Boll Illerup ${ }^{\mathrm{b}}$, Adam Paul Karcz ${ }^{\mathrm{b}}$, Shufeng Ye ${ }^{\mathrm{a}}$, Anne Juul Dam $\emptyset^{b^{*}}$

${ }^{\text {a }}$ State Key Laboratory of Multiphase Complex Systems, Institute of Process Engineering, Chinese Academy of Sciences, North 2nd Street, Zhongguancun, Haidian District, Beijing, PR China

${ }^{b}$ Department of Chemical and Biochemical Engineering, Technical University of Denmark, Søltofts Plads, Building 229, DK-2800 Kongens Lyngby, Denmark

${ }^{c}$ Sino-Danish College, University of Chinese Academy of Sciences, 380 Huaibeizhuang, Huairou district, Beijing, PR China

* Corresponding authors:

Hao Wu: Tel.: +45 45252927; Fax: +45 45882258. E-mail: haw@kt.dtu.dk.

Anne Juul Damø: Tel.: +45 4525 2800; Fax: +45 4588 2258. E-mail: ajp@kt.dtu.dk 


\begin{abstract}
A key component in the atmospheric leaching of metal sulfides is the oxidation of sulfide to either elemental sulfur or hexavalent sulfur. The final oxidation state of sulfur significantly influences the economic viability of a leaching process because of its effects on oxygen consumption, acid generation, and surface passivation. Thus, in the process of developing new leaching technologies, it is important to both characterize and quantify the sulfur oxidation products. In this work, a new method based on Simultaneous Thermal Analysis (STA) is established for the quantification and thermal characterization of elemental sulfur in chalcopyrite leach residues. The STA method refers to the simultaneous application of thermogravimetric analysis (TGA) and differential scanning calorimetry (DSC). The DSC measurements yield information on phase transformation, which can be used to identify the sulfur allotropes. The linear relationship between the melting enthalpy of $\beta$-sulfur determined by DSC and the sulfur content determined by TGA is expediently used to quantify the unknown sulfur content in leach residues.
\end{abstract}

Keywords: Chalcopyrite leach residue; Elemental sulfur; Allotrope; Quantification; STA. 


\section{Introduction}

As an alternative to pyrometallurgical processes, hydrometallurgical extraction of copper from chalcopyrite $\left(\mathrm{CuFeS}_{2}\right)$ has the advantages of less environmental pollution and greater ability to treat low-grade ores, especially those containing a significant amount of detrimental elements, such as arsenic, bismuth, zinc and lead (Berezowsky and Trytten, 2002; Braithwaite and Wadsworth, 1976). Among the various hydrometallurgical extraction processes to treat chalcopyrite, acidic ferric ion leaching is believed to be a promising and low-cost route to produce pure copper (Córdoba et al., 2008; Dutrizac, 1982; Javier, 2009). However, the leaching process is difficult to carry out under atmospheric pressure because of the unique electronic structure of chalcopyrite and the complexity of the reaction pathways (Crundwell, 2015; Osseo-Asare, 1992). It has been found that as the acidic ferric ion leaching reaction proceeds (indicated by Eq. 1 and Eq. 2), a passivation layer is formed on the surface of the chalcopyrite particles. This results in slow kinetics and poor copper recoveries due to the formation of a diffusion barrier between the solution and chalcopyrite grains (Ghahremaninezhad et al., 2010; Ghahremaninezhad et al., 2012; Olvera et al., 2016; RiveraVasquez et al., 2015; Wang et al., 2016). Although there is still some controversy about the exact composition of this passivation layer, elemental sulfur or polysulfides are observed consistently and considered as systemic products in the acidic ferric ion dissolution of chalcopyrite (Córdoba et al., 2008; Córdoba et al., 2009; Klauber, 2008).

$$
\begin{array}{r}
\mathrm{CuFeS}_{2}(\mathrm{~s})+4 \mathrm{Fe}^{3+}(\mathrm{aq}) \rightarrow \mathrm{Cu}^{2+}(\mathrm{aq})+5 \mathrm{Fe}^{2+}(\mathrm{aq})+2 \mathrm{~S}^{0}(\mathrm{~s}) \ldots \ldots \ldots . . . \\
4 \mathrm{Fe}^{2+}(\mathrm{aq})+\mathrm{O}_{2}(\mathrm{~g})+4 \mathrm{H}^{+}(\mathrm{aq}) \rightarrow 4 \mathrm{Fe}^{3+}(\mathrm{aq})+2 \mathrm{H}_{2} \mathrm{O}(\mathrm{l}) \ldots \ldots \ldots \ldots . . \\
\mathrm{CuFeS}_{2}(\mathrm{~s})+4 \mathrm{Fe}^{3+}(\mathrm{aq})+3 \mathrm{O}_{2}(\mathrm{aq})+2 \mathrm{H}_{2} \mathrm{O}(\mathrm{l}) \rightarrow \mathrm{Cu}^{2+}(\mathrm{aq})+5 \mathrm{Fe}^{2+}(\mathrm{aq})+2 \mathrm{H}_{2} \mathrm{SO}_{4}(\mathrm{aq})
\end{array}
$$

In the most simple and widespread model for passivation by sulfur products, these products are not released into solution at room temperature, but form an electrically non-conductive layer at the surface of the particles. Hence, the overall reaction rate is decreased by inhibiting the electron transfer through the surface sulfur, eventually leading to passivation of the leaching process (Nazari et al., 2012; Pradhan et al., 2008). Wan et al. (1984) found that only 40\% copper was extracted from chalcopyrite due to the produced sulfur, and the leaching rate was regained after the elimination of sulfur layer by distillation under a nitrogen atmosphere, proving the inhibition effect of elemental sulfur. Havlik and Kammel (1995) found that when chalcopyrite was oxidized in the presence of carbon tetrachloride, copper extraction was significantly increased. 
To address the passivation problem, global engineering company FLSmidth ${ }^{\circledR}$ has developed a mechanochemical approach, i.e., the FLSmidth ${ }^{\circledR}$ Rapid Oxidative Leach (ROL) process for atmospheric leaching of chalcopyrite in acidic ferric sulfate. The process can provide more than $97 \%$ copper recovery in $6 \mathrm{~h}$ or less. The ROL process includes a chemical activation step as pretreatment and a downstream mechanochemically assisted leaching step that fractures partially leached particles and mitigates the passivation processes (Chaiko et al., 2015a, 2015b; Karcz et al., 2017; Eyzaguirre et al., 2015). In the ROL process, some of the chalcopyrite sulfide is advantageously oxidized to sulfuric acid, as shown in Eq. 3, which is an economic and operational benefit. This is because the produced sulfuric acid can replenish the acidity required for the leaching process, as shown in Eq. 2 (Dutrizac and MacDonald, 1974; Gómez et al., 1996). However, the final sulfur species in the leach product is not well understood. As the sulfur products can have significant impact on oxygen consumption, acid generation, and surface passivation of the leaching process, it is important to establish a method to characterize and identify the sulfur species in the leach product (McDonald and Muir, 2007; Sahu and Asselin, 2011).

In this paper, a method based on Simultaneous Thermal Analysis (STA) is developed and tested to analyze the elemental sulfur in the residue obtained from the FLSmidth ${ }^{\circledR}$ ROL process. The STA method employs the simultaneous application of thermogravimetric analysis (TGA) and differential scanning calorimetry (DSC). The combined DSC and TGA signals can provide qualitative information about the sulfur allotropes present in the sample. By using model compounds containing elemental sulfur, quartz, and chalcopyrite, a method for quantifying the amount of elemental sulfur in the leach residue is established and validated.

\section{Materials and Methods}

\subsection{Materials}

The chalcopyrite leach residue used in the present work was obtained from the FLSmidth ${ }^{\circledR}$ ROL process (Chaiko et al., 2015a; Chaiko et al., 2015b; Eyzaguirre et al., 2015). The feed copper concentrate with 24 wt. \% Cu (shown in Table S1) was slurry split. The primary crystalline phases present in the feed material (according to the XRD analysis in Figure S1) were chalcopyrite, pyrite, and quartz. The feed material was leached in acidic ferric sulfate media at $80{ }^{\circ} \mathrm{C}$ with an initial iron concentration of $20 \mathrm{~g} / \mathrm{L}$, in accordance with the FLSmidth ${ }^{\circledR}$ ROL procedure described in detail in

61 Chaiko et al. (2015a). At the end of the leach experiment, the residue was filtered and dried, and the 62 
63 characterized by the methods described in Section 2.2. Elemental sulfur ( $\alpha$-sulfur, powder, $>99.98 \%$ trace metals basis) and quartz powder were purchased from Sigma-Aldrich. Pure chalcopyrite mineral was purchased from Alfa Aesar and was ground to $100 \%<74 \mu \mathrm{m}$ with an agate mortar and pestle. Toluene of anhydrous grade and assay $\geq 99.8 \%$ was purchased from Sigma-Aldrich.

\subsection{Analytical methods}

The elemental composition of the leach residue was analyzed by Inductively Coupled Plasma Optical Emission Spectrometry (ICP-OES). The sample was dried overnight to remove moisture. A sample of $0.050 \mathrm{~g}$ was mixed with $2 \mathrm{~mL} \mathrm{H}_{2} \mathrm{O}_{2}, 7.5 \mathrm{~mL} \mathrm{HNO}_{3}$ and $1.7 \mathrm{~mL} \mathrm{HF} \mathrm{(48 \% )} \mathrm{and} \mathrm{digested} \mathrm{in}$ a high-pressure reactor, which was heated to $210^{\circ} \mathrm{C}$ within $10 \mathrm{~min}$ and kept at this temperature for $15 \mathrm{~min}$. Then, the solution was cooled and neutralized with $20 \mathrm{~mL} \mathrm{H}_{3} \mathrm{BO}_{3}(4 \% \mathrm{w} / \mathrm{v})$ and diluted to $100 \mathrm{~mL}$ with ultrapure water prior to ICP-OES analysis based on the standard DS/EN ISO 11885.

The X-Ray Diffraction (XRD) analysis of crystalline phases in the leach residue was carried

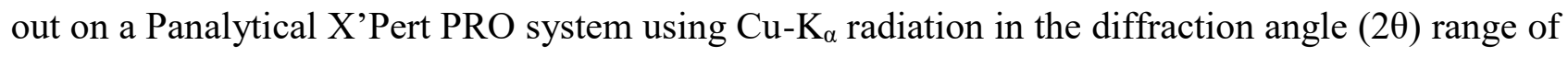
$3^{\circ}-100^{\circ}$. The crystalline phases were identified by Crystallgraphica Search Match software to reference the relevant peaks to the standard diffraction database (PDF-2 2004 from ICDD).

The compositions of the leach residue and mixed pure mineral standards were characterized using a field emission Scanning Electron Microscope (SEM, JEOL 2100F), equipped with an Energy Dispersive Spectrometer (EDS). Samples of 1 - $2 \mathrm{~g}$ were embedded within resin and curing agent for 12 hours. Then, the cured sample was polished on SiC pads of 200-mesh, 800-mesh, 1200-mesh, and 2000-mesh in preparation for measurement by SEM-EDS.

The thermal behavior of minerals in the residue was evaluated by STA using a Netzsch STA 449F1 instrument. During the experiments, the sample was placed in an alumina crucible, with an empty crucible alongside as a reference. Unless otherwise stated, the furnace was heated from $25^{\circ} \mathrm{C}$ to $400{ }^{\circ} \mathrm{C}$ for all experiments. Different heating rates and heating programs (heating-cooling cycles) were applied for the establishment of the STA characterization method. The relevant details for the different experiments are provided in the Results and Discussion (Section 3). Nitrogen purge gas with a purity of $99.9 \%$ was used as the protective gas with a flow of $100 \mathrm{~mL} / \mathrm{min}$. All STA data were baseline-corrected using a scan of an empty crucible. The analyses of DSC and TGA curves were done using NETZSCH Proteus Thermal Analysis software. As illustrated in Figure 1, the derivatives of the DSC and TGA curves were used to identify the onset and endpoint of the mass or heat changes when calculating the mass loss or the reaction enthalpy (Chiu, 1963; Gill et al., 2010; Munther et al., 2010). In this paper, all the enthalpy and mass change calculations were based on the 
method above. In order to simplify the presentation, the derivative curves for the DSC and TGA data were omitted in each figure.
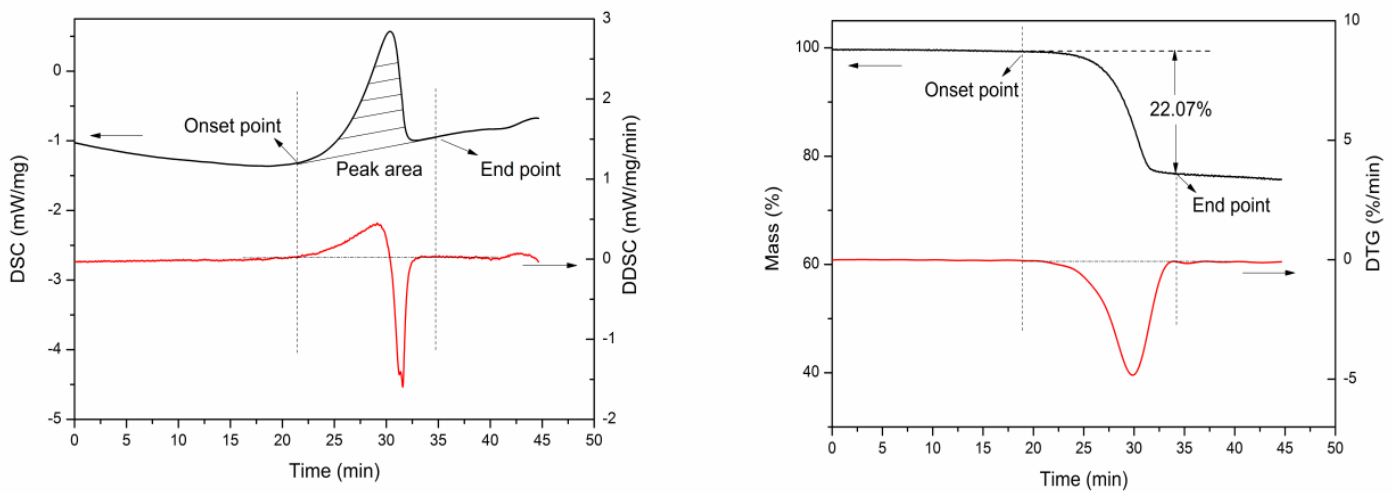

a. DSC

b. TGA

Figure 1. Schematic diagram for the calculation of DSC (a) and TGA (b).

The mass fraction of elemental sulfur in the leach residue can be determined gravimetrically by toluene extraction. Extraction of sulfur by organic solutions, such as carbon disulfide and carbon tetrachloride, is often used to quantify the amount of sulfur (Meyer et al., 1971; Sciamanna and Lynn, 1988). However, the potentially carcinogenic nature of these solvents makes their use undesirable. Sulfur is also soluble in solvents such as toluene, cyclohexane, octane, and dry methanol (Jay et al., 2009). In this experiment, toluene was chosen as the solvent based on the high elemental sulfur solubility. Approximate $3 \mathrm{~g}$ sub-sample of leach residue was added to toluene at $60{ }^{\circ} \mathrm{C}$. The mixture was stirred for $15-20 \mathrm{~min}$ at $600 \mathrm{rpm}$ after which the slurry was filtered and the solids were washed with warm toluene. The residual solid was dried in an oven at $50{ }^{\circ} \mathrm{C}$ to constant weight. The percentage of elemental sulfur was calculated by Eq. 4 .

$$
\text { wt. } \% \text { of sulfur }=\frac{\text { initial sample mass-residual sample mass }}{\text { initial sample mass }} \times 100 \%
$$

\section{Results and discussion}

\subsection{Elemental composition and mineral phases in the leach residue}


The elemental composition of the leach residue is shown in Table 1. From Table 1, we can see 115 that $\mathrm{S}$ is the predominant element, which consists of $65.0 \mathrm{wt} . \%$. The content of Si is high (8.7 wt.\%), 116 and together with $\mathrm{Al}, \mathrm{K}$, and $\mathrm{Mg}$, they may constitute the gangue minerals. There are also $2.6 \%$ of $117 \mathrm{Cu}$ and $2.4 \%$ of $\mathrm{Fe}$ in the residue. Other elements such as $\mathrm{Ca}, \mathrm{Na}$, and $\mathrm{P}$ are present in minor 118 amounts of less than $0.1 \mathrm{wt} . \%$. The XRD pattern in Figure 2 shows that the primary crystalline 119 phases detected are elemental sulfur $\left(\mathrm{S}^{0}\right)$, quartz $\left(\mathrm{SiO}_{2}\right)$, and chalcopyrite $\left(\mathrm{CuFeS}_{2}\right)$. The pattern for 120 sulfur is very sharp and strong, which is consistent with the large content of elemental sulfur 121 detected by ICP-OES. Other elements were not detected as their host minerals by XRD (which may 122 be due to their low contents).

123 Figure 3 shows the morphology and EDS point analysis of the leach residue. It seems that most 124 of the sample particles adhere to each other, possibly because of the large amount of sulfur. The 125 EDS results show that the bright points contain mostly $\mathrm{S}, \mathrm{Fe}$, and $\mathrm{Cu}$ (see Figure 3e Spectrum 3 and 126 Figure 3f Spectrum 1), indicating the presence of chalcopyrite. Figure 3e Spectrum 1 contains 127 mainly $\mathrm{S}, \mathrm{Co}$, and $\mathrm{Cu}$, indicating the possibility of carrollite $\left(\mathrm{CuCo}_{2} \mathrm{~S}_{4}\right)$. The gray point (see Figure 128 3f Spectrum 2) contains $\mathrm{Mg}, \mathrm{Al}, \mathrm{Si}$, and $\mathrm{S}$, indicating that it is mostly composed of silicate and/or 129 muscovite. The further gray points (see Figure 3e Spectrum 2 and Figure 3f Spectrum 3) contain 130 abundant sulfur. It appears that sulfur is poriferous. The particle size distribution (PSD) of the leach 131 residue (see Figure S2 in supplementary materials) reveals a fine-mode peak in the interval from $1320.40 \mu \mathrm{m}$ to $20 \mu \mathrm{m}$. The PSD in terms of volume distribution $\left(\mathrm{D}_{\mathrm{v}}\right)$ values for the leach residue was: $133 \mathrm{D}_{\mathrm{v}}(10)=1.11 \mu \mathrm{m}, \mathrm{D}_{\mathrm{v}}(50)=3.83 \mu \mathrm{m}, \mathrm{D}_{\mathrm{v}}(90)=9.36 \mu \mathrm{m}$. About $10 \%$ of the leach residue is $>9.36 \mu \mathrm{m}$, 134 which may be due to the unreacted minerals in chalcopyrite concentrate.

135 Table 1. Elemental composition of the leach residue (wt.\%) as determined by ICP-OES.

\begin{tabular}{ccccccc}
\hline Element & $\mathbf{S}$ & $\mathbf{S i}$ & $\mathbf{C u}$ & $\mathbf{F e}$ & $\mathbf{A l}$ & $\mathbf{C o}$ \\
$\mathbf{w} / \%$ & 65.0 & 8.7 & 2.6 & 2.4 & 2.1 & 1.3 \\
\hline Element & $\mathbf{K}$ & $\mathbf{M g}$ & $\mathbf{T i}$ & $\mathbf{C a}$ & $\mathbf{N a}$ & $\mathbf{P}$ \\
$\mathbf{w} / \%$ & 0.86 & 0.45 & 0.18 & $<0.1$ & $<0.1$ & $<0.1$ \\
\hline
\end{tabular}


136

137

138

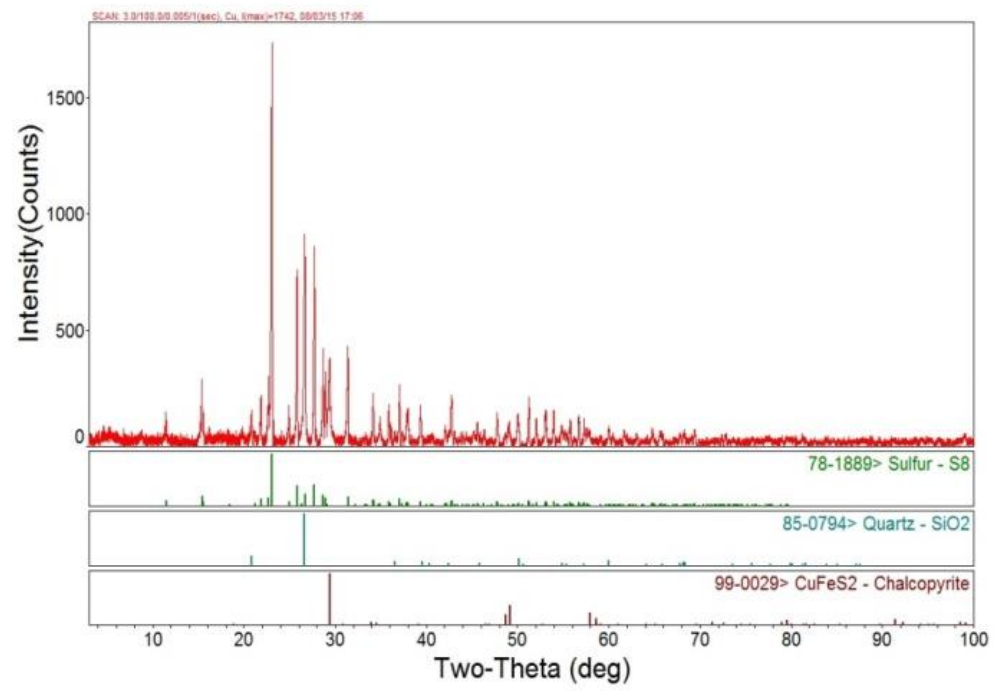

Figure 2. XRD analysis of the leach residue.

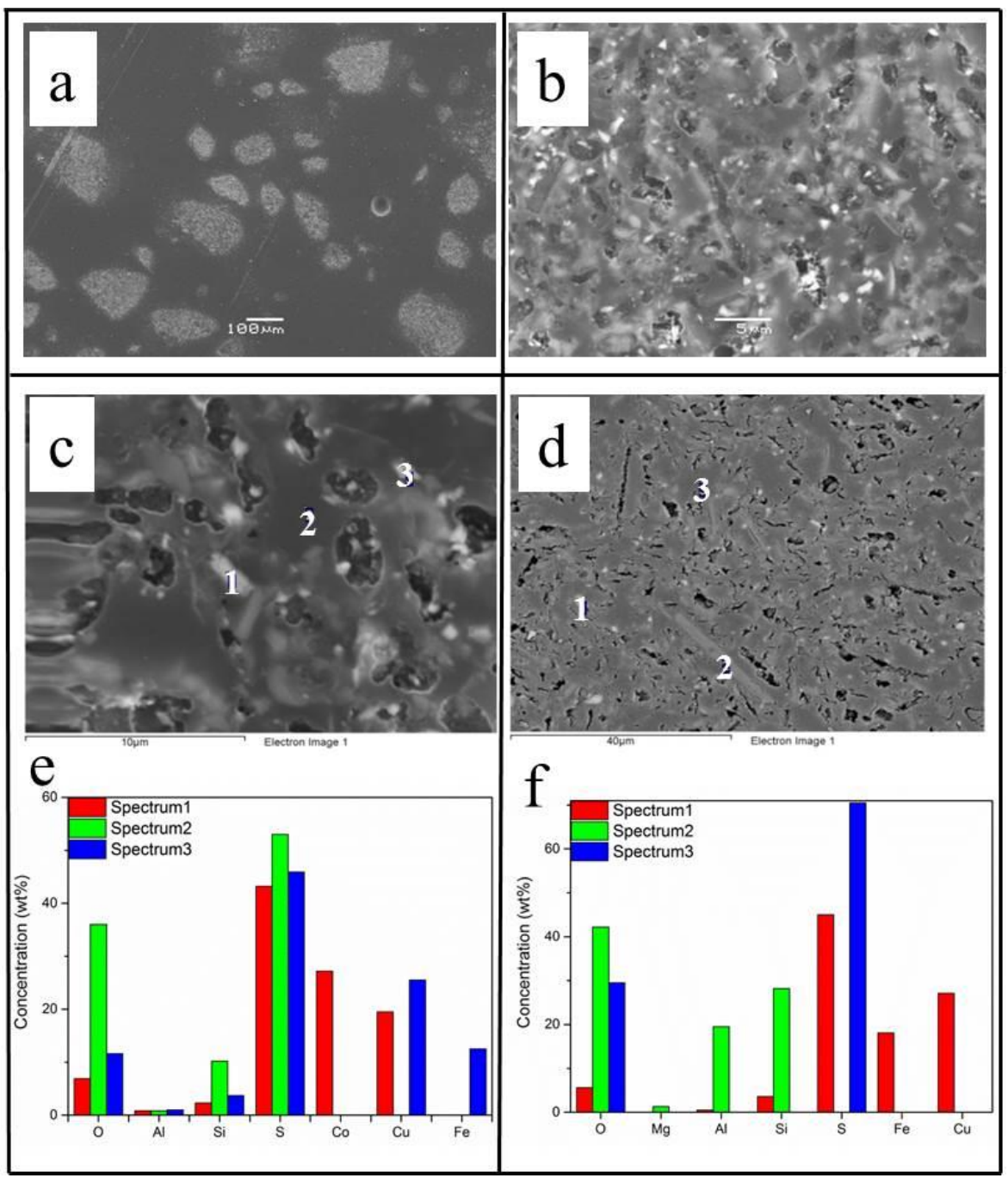

Figure 3. Morphology and composition of leach residue as determined by SEM-EDS. 


\subsection{STA analysis of leach residue}

As previously stated, STA is a combined technique of DSC and TGA, which can be used to analyze the elemental sulfur thermal properties. Elemental sulfur can exist as a number of different allotropes. Table S2 (see supplementary materials) compiles data for different sulfur phase transitions at different temperatures. In view of these phase transition data, it is possible to use STA to identify the phases of elemental sulfur in chalcopyrite leach residue. The STA of the leach residue is shown in Figure 4, with the cycle heating program as follows (heating/cooling rates of $2{ }^{\circ} \mathrm{C} / \mathrm{min}, \mathrm{N}_{2}$ flow of $100 \mathrm{~mL} / \mathrm{min}$, samples mass of $10 \mathrm{mg}$ ):

First stage $\left(1^{\text {st }}\right.$ stage $)$ : Heating from $25^{\circ} \mathrm{C}$ to $130{ }^{\circ} \mathrm{C}$;

Second stage $\left(2^{\text {nd }}\right.$ stage $)$ : Cooling from $130{ }^{\circ} \mathrm{C}$ to $25^{\circ} \mathrm{C}$;

Third stage $\left(3^{\text {rd }}\right.$ stage $)$ : Heating from $25^{\circ} \mathrm{C}$ to $150{ }^{\circ} \mathrm{C}$;

Fourth stage $\left(4^{\text {th }}\right.$ stage $)$ : Continuous heating from $150{ }^{\circ} \mathrm{C}$ to $400{ }^{\circ} \mathrm{C}$.

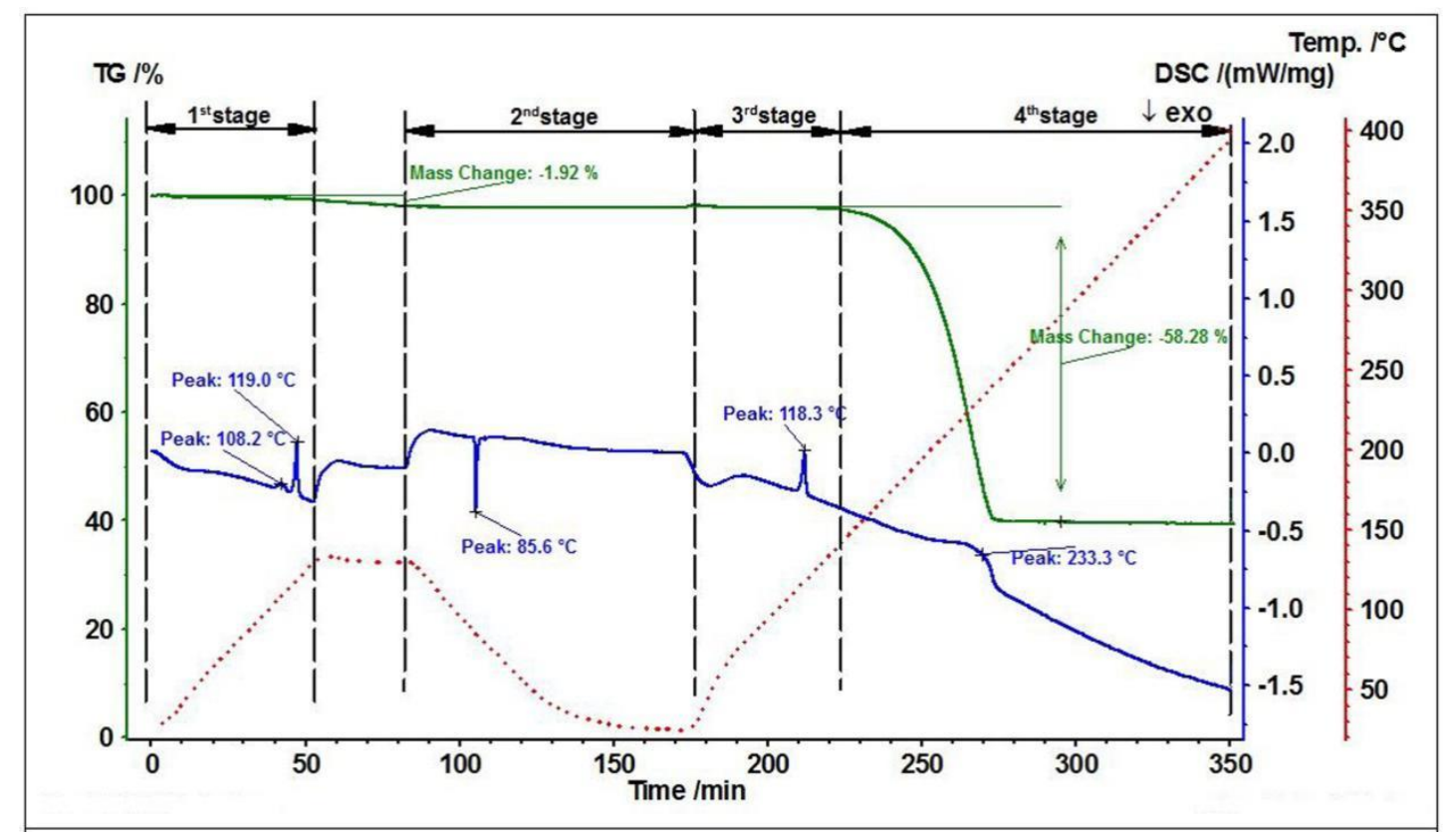

Figure 4. STA of leach residue with cycle heating program.

\subsubsection{The DSC curve}

\subsubsection{First stage}

At this stage, the sample is heated from $25{ }^{\circ} \mathrm{C}$ to $130{ }^{\circ} \mathrm{C}$. Figure 4 shows two distinct endothermic peaks at $108.2{ }^{\circ} \mathrm{C}$ and $119.0{ }^{\circ} \mathrm{C}$ for the leach residue. From similar STA analyses of pure mineral samples (Figure S3-S6 in supplementary materials), it can be seen that there are no 
endothermic peaks or exothermic peaks for quartz, chalcopyrite, or pyrite below $130{ }^{\circ} \mathrm{C}$ shown by DSC, while there are two clear endothermic peaks at $108.7^{\circ} \mathrm{C}$ and $123.1{ }^{\circ} \mathrm{C}$ for pure sulfur. Except for the slight shift in peak temperatures, the appearances of the DSC curves for the leach residue (Figure 4) and pure sulfur are quite consistent. Assuming that the shifts in peak temperatures reflect that the leach residue contains impurities as compared to the pure sulfur sample (which is further evidenced in Section 4.1, Figure 5, and Table S2), the results strongly indicate that the two endothermic peaks of the $1^{\text {st }}$ stage are caused by the transformation of elemental sulfur.

According to Table S2, the small endothermic peak at $108.2^{\circ} \mathrm{C}$ indicates either the depressed melting point of orthorhombic sulfur ( $\alpha$-sulfur), or the solid-solid transformation of $\alpha$-sulfur into monoclinic sulfur ( $\beta$-sulfur). In the work of Ficara and Moreira, there are two endothermic peaks at $108.25^{\circ} \mathrm{C}$ and $119.50{ }^{\circ} \mathrm{C}$ for the DSC of standard sulfur, which represent the $\alpha$-sulfur to $\beta$-sulfur transition and the melting of sulfur, respectively (Ficara and Moreira, 1988). Their measurement conditions are very close to this study; thus, the first peak at $108.2{ }^{\circ} \mathrm{C}$ could be assigned to the transformation of $\alpha$-sulfur into $\beta$-sulfur (Laitinen and Niinisto, 1978; Miller, 1971; Thackray, 1970). Meanwhile, the peak at $119.0{ }^{\circ} \mathrm{C}$ is most probably due to the melting of $\beta$-sulfur. Different melting points have been reported for $\beta$-sulfur. "Natural" $\beta$-sulfur should melt at $114.6{ }^{\circ} \mathrm{C}$, while melting temperatures of $119.6{ }^{\circ} \mathrm{C}$ and $120.4{ }^{\circ} \mathrm{C}$ have been reported for regular and microcrystalline $\beta$-sulfur, respectively (Koningsberger and De Neef, 1972; Meyer, 1964; Meyer 1976; Thackray, 1970).

The integrated DSC peak area can be used to determine the enthalpy of phase transition, and thus, a peak area analysis of the DSC scans can be used to support the above conclusions regarding sulfur allotropes present in the leach residue. The area of the first endothermic peak at $108.2{ }^{\circ} \mathrm{C}$ suggests an endothermic enthalpy of $5.73 \mathrm{~J} / \mathrm{g}$, which is about $1 / 4$ of the heat absorption of the second peak at $119.0{ }^{\circ} \mathrm{C}(22.08 \mathrm{~J} / \mathrm{g})$. According to the thermal data for phase transitions of sulfur, the enthalpy for the $\alpha-\beta$ sulfur transition is $12.56 \mathrm{~J} / \mathrm{g}$, while it is $50.25 \mathrm{~J} / \mathrm{g}$ for the melting of $\beta$-sulfur (the value differences lie in various samples), which corresponds to a ratio of about 1:4 (Meyer, 1964; Meyer, 1976; Hemingway, 1999). Hence, it is plausible to conclude that the two peaks in the $1^{\text {st }}$ stage represent the $\alpha-\beta$ sulfur transition and the melting of $\beta$-sulfur, respectively. The good quantitative agreement (the 1:4 ratio) also suggests that the only sulfur allotrope present at the beginning of the analysis is the stable $\alpha$-sulfur allotrope.

\subsubsection{Second stage}


During this stage, the sample is cooled from $130{ }^{\circ} \mathrm{C}$ to $25^{\circ} \mathrm{C}$. A distinct exothermic peak is present at $85.6{ }^{\circ} \mathrm{C}$, and this peak is most likely attributed to the recrystallization of $\beta$-sulfur. A temperature of around $50{ }^{\circ} \mathrm{C}$ for recrystallization of $\beta$-sulfur has been reported elsewhere (Perrenot and Widmann, 1994). The much higher phase change temperature in our case can be ascribed to the content of other minerals (impurities) in the leach residue sample, and this is further discussed in Section 4.1.

\subsubsection{Third stage}

In this stage, the sample is heated from $25{ }^{\circ} \mathrm{C}$ to $150{ }^{\circ} \mathrm{C}$. The distinct endothermic peak at $118.3^{\circ} \mathrm{C}$ is probably the re-melting of $\beta$-sulfur as compared with the melting of $\beta$-sulfur in the $1^{\text {st }}$ stage, indicating the sole presence of $\beta$-sulfur in the residue after heat treatment. In support of this, additional DSC investigations of the re-melting of sulfur allotropes in leach residue are presented in Figure S7 of the supplementary materials. The heat flux of the single endothermic peak at $118.3{ }^{\circ} \mathrm{C}$ gives a value of $21.27 \mathrm{~J} / \mathrm{g}$, which is approximately equivalent to the $1^{\text {st }}$ stage, further evidencing that

\subsubsection{Fourth stage}

The sample is heated from $150{ }^{\circ} \mathrm{C}$ to $400{ }^{\circ} \mathrm{C}$. At this stage, there is a distinct mass loss after a small endothermic peak at around $165.0^{\circ} \mathrm{C}$. According to Miller $(1964,1971)$, the melted $\beta$-sulfur can transform into the lambda form of sulfur ( $\lambda$-sulfur), which can polymerize to form catena-sulfur

\subsubsection{The TGA curve} (Meyer, 1964; Meyer, 1976). With the increase of temperature, the catena-sulfur begins to vaporize at around $233.3{ }^{\circ} \mathrm{C}$ and leads to the obvious mass loss.

The TGA curve is also plotted in Figure 4. The result reveals a small mass loss of $1.92 \%$ during the $130{ }^{\circ} \mathrm{C}$ isothermal stage. As shown in Figure S3, there is a slight mass loss for pure sulfur before $130{ }^{\circ} \mathrm{C}$, while in Figure S4 - S6, the mass losses for quartz, chalcopyrite, and pyrite between $25{ }^{\circ} \mathrm{C}-130{ }^{\circ} \mathrm{C}$ are $0.18 \%, 0.34 \%$, and $0.29 \%$, respectively, which may be due to other labile substance in these samples. Thus, it is concluded that the $1.92 \%$ mass loss is probably due to the slight sulfur loss during the isothermal stage. During the fourth stage, there is a distinct mass loss of $58.28 \%$, which can be explained by the vaporization of sulfur. 


\section{Quantification of the leach residue}

\subsection{Establishment of quantification method by STA}

Based on the characterization of the leach residue in Section 3.1, we identified the main mineral phases in the leach residue as sulfur, quartz, and chalcopyrite (with the contents of other compositions being below $4 \mathrm{wt}$ \%). Synthetic samples consisting of pure elemental sulfur $\left(\mathrm{S}^{0}\right)$, pure chalcopyrite $\left(\mathrm{CuFeS}_{2}\right)$, and pure quartz $\left(\mathrm{SiO}_{2}\right)$ in different ratios were prepared and measured by

231 STA in order to verify the STA measurement method and formulate a melting enthalpy-based standard curve for the measurement of leach residues. Different amounts of pure elemental sulfur,

233 chalcopyrite, and quartz were weighed using an electronic balance with $0.01 \mathrm{mg}$ accuracy to produce ratios for $\mathrm{S}^{0}: \mathrm{CuFeS}_{2}: \mathrm{SiO}_{2}$ of $2.7: 1: 3,4.8: 1: 3,15.3: 1: 3,1: 0: 0$, which were given the sample identities J1, J2, J3, and J4, respectively. The mixed mineral samples were then ground in an agate mortar to $<200$ mesh. The STA measurements of the synthetic samples with different sulfur contents are shown in Figure 5 and Table 2. The conditions are the same as the cycle heating of the leach residue in Section 3.2. With regard to the synthetic samples, the STA analysis was also divided into four stages, which are interpreted next.

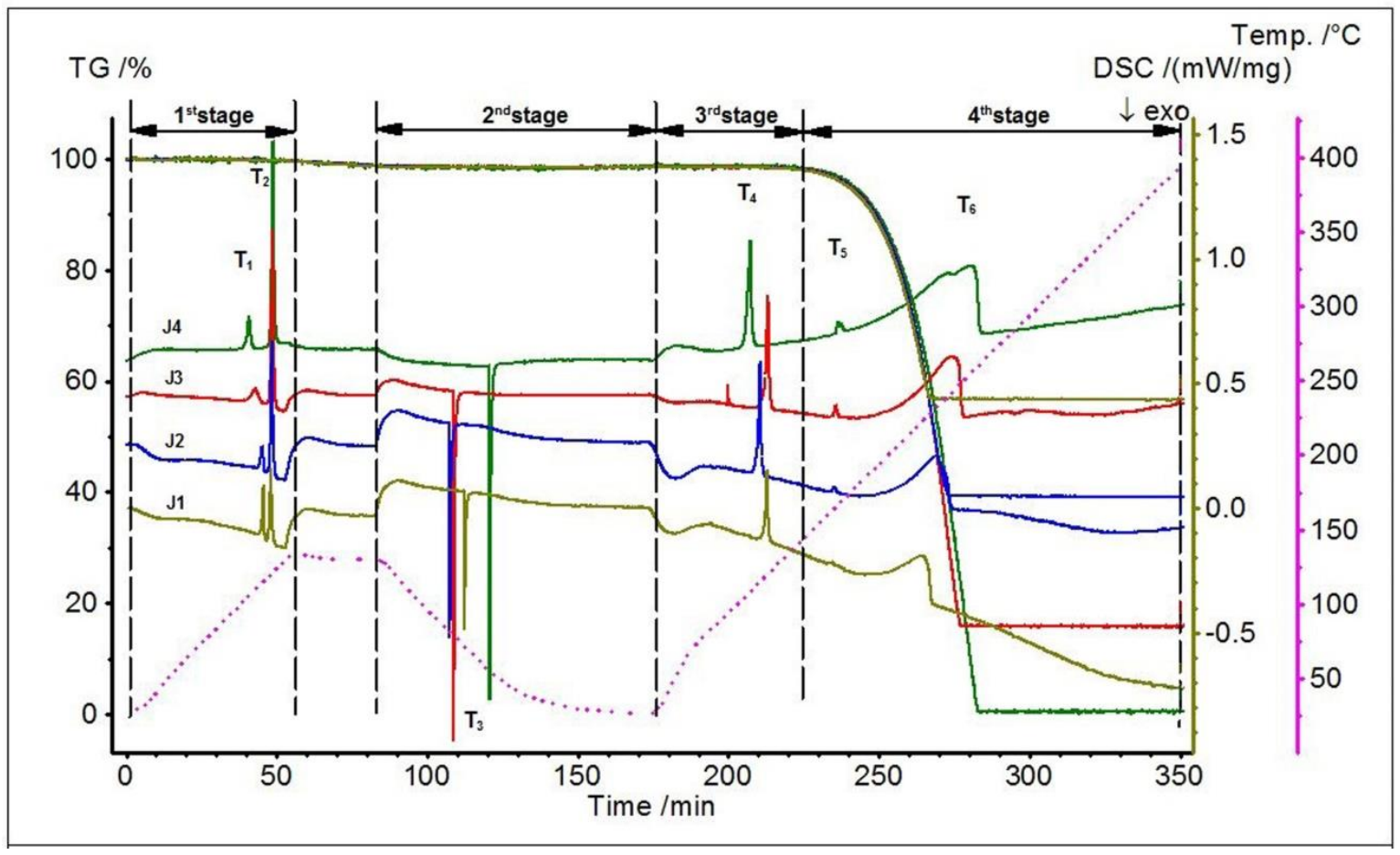

Figure 5. STA of synthetic samples with different sulfur contents. 
Table 2. Peak temperatures for different synthetic samples according to STA analysis.

\begin{tabular}{cccccccc}
\hline \multirow{2}{*}{ Sample } & \multirow{2}{*}{$\begin{array}{c}\mathbf{S}: \mathbf{C u F e S}_{\mathbf{2}}: \mathbf{S i O}_{\mathbf{2}} \\
\text { ratios }\end{array}$} & \multicolumn{2}{c}{ First stage } & $\begin{array}{c}\text { Second } \\
\text { stage }\end{array}$ & $\begin{array}{c}\text { Third } \\
\text { stage }\end{array}$ & \multicolumn{2}{c}{ Fourth stage } \\
\cline { 2 - 8 } & & $\mathbf{T}_{\mathbf{1}}\left({ }^{\circ} \mathrm{C}\right)$ & $\mathbf{T}_{\mathbf{2}}\left({ }^{\circ} \mathrm{C}\right)$ & $\mathbf{T}_{\mathbf{3}}\left({ }^{\circ} \mathrm{C}\right)$ & $\mathbf{T}_{\mathbf{4}}\left({ }^{\circ} \mathrm{C}\right)$ & $\mathbf{T}_{\mathbf{5}}\left({ }^{\circ} \mathrm{C}\right)$ & $\mathbf{T}_{\mathbf{6}}\left({ }^{\circ} \mathrm{C}\right)$ \\
\hline $\mathbf{J 1}$ & $2.7: 1: 3$ & 115.5 & 120.6 & 71.4 & 120.4 & 162.6 & 222.9 \\
$\mathbf{J 2}$ & $4.8: 1: 3$ & 114.6 & 121.2 & 81.0 & 115.4 & 164.4 & 232.0 \\
$\mathbf{J 3}$ & $15.3: 1: 3$ & 110.0 & 121.6 & 78.4 & $93.9 /$ & 165.7 & 242.2 \\
$\mathbf{J 4}$ & $1: 0: 0$ & 106.0 & 121.8 & 54.9 & 108.9 & 167.2 & 255.3 \\
\hline
\end{tabular}

\subsubsection{First stage}

At this stage, there are two distinct endothermic peaks at around $110.0^{\circ} \mathrm{C}$ and $121.0^{\circ} \mathrm{C}$ for the four samples. Table 2 shows that the temperature of peak $\mathbf{T 1}$ is reduced with the increase of the sulfur content in the synthetic samples, indicating that the conversion of sulfur proceeds slowly near the transformation temperature, which can be again assigned to the $\alpha$-sulfur to $\beta$-sulfur transformation (Donohue, 1974; Sands, 1965). It has been reported that the transformation time is

251 influenced by the purity of the sample (Steudel, 1984). The peak $\mathbf{T} 2$ at around $120.0^{\circ} \mathrm{C}$ is likely the 252 melting of $\beta$-sulfur, which typically occurs at around $119^{\circ} \mathrm{C}$ (Meyer, 1964). It is noticeable that the $253 \beta$-sulfur melting temperature changes little with the increase of sulfur content.

\subsubsection{Second stage}

During this stage, the samples are cooled from $130{ }^{\circ} \mathrm{C}$ to $25^{\circ} \mathrm{C}$. A distinct exothermic peak $\mathbf{T 3}$

258 Similarly, the exothermic peak in synthetic samples may also be attributed to the recrystallization of $259 \beta$-sulfur (or a mixture of $\beta$-sulfur and other cyclic molecules) (Perrenot and Widmann, 1994). The 260 increased recrystallization temperature of mixed mineral samples as compared to the pure sulfur 261 sample (J4) may be explained by the presence of other minerals (such as quartz) in the sample, 262 which can "seed" the crystallization of sulfur.

\subsubsection{Third stage}

In this stage, the samples are heated from $25^{\circ} \mathrm{C}$ to $150{ }^{\circ} \mathrm{C}$. The distinct endothermic peak $\mathbf{T} 4$ position at $108.9{ }^{\circ} \mathrm{C}, 120.7{ }^{\circ} \mathrm{C}, 115.4{ }^{\circ} \mathrm{C}$, and $120.4{ }^{\circ} \mathrm{C}$ for the four samples, respectively. As compared to the melting point of what is supposed to be monoclinic $\beta$-sulfur during the first stage 
heating (around $120.3{ }^{\circ} \mathrm{C}$ ), the positions of the peak for samples $\mathrm{J} 2$ and $\mathrm{J} 4$ are shifted significantly toward lower temperatures. This indicates that the re-crystallized sulfur formed during the second stage is another (metastable) allotrope of sulfur instead of monoclinic $\beta$-sulfur or the mixture of sulfur allotropes. Meyer (1964) suggests that it is probably the melting of monoclinic $\gamma$-sulfur (m.p. $106.8^{\circ} \mathrm{C}$ ). This allotrope of sulfur can be obtained from a solution of cyclo-S $\mathrm{S}_{8}$ and from its melt

273 (which would be the case here).

\subsubsection{Fourth stage}

At this stage, the samples are heated from $150{ }^{\circ} \mathrm{C}$ to $400{ }^{\circ} \mathrm{C}$. There are also small endothermic peaks at around $165.0^{\circ} \mathrm{C}$ for the four samples, which could be assigned to the production of $\lambda$ sulfur. With the increase of temperature, the $\lambda$-sulfur evaporates within one hour (Currell and Williams, 1974; Steudel and Eckert, 2003).

\subsubsection{The TGA curves}

Examination of the TGA curves indicates the performance of the four synthetic samples are almost the same as the leach residue, with small mass losses of $1.62 \%$ during the $130{ }^{\circ} \mathrm{C}$ isothermal 284 stage and large mass losses above $150{ }^{\circ} \mathrm{C}$, as shown in Table 3 . There are total mass losses of $41.82 \%, 59.31 \%, 82.62 \%$, and $98.13 \%$ for $\mathrm{J} 1, \mathrm{~J} 2, \mathrm{~J} 3$ and $\mathrm{J} 4$, respectively, which are all close to the theoretical sulfur contents using toluene extraction method in samples given the high purity of the sulfur used, as verified in Table S3.

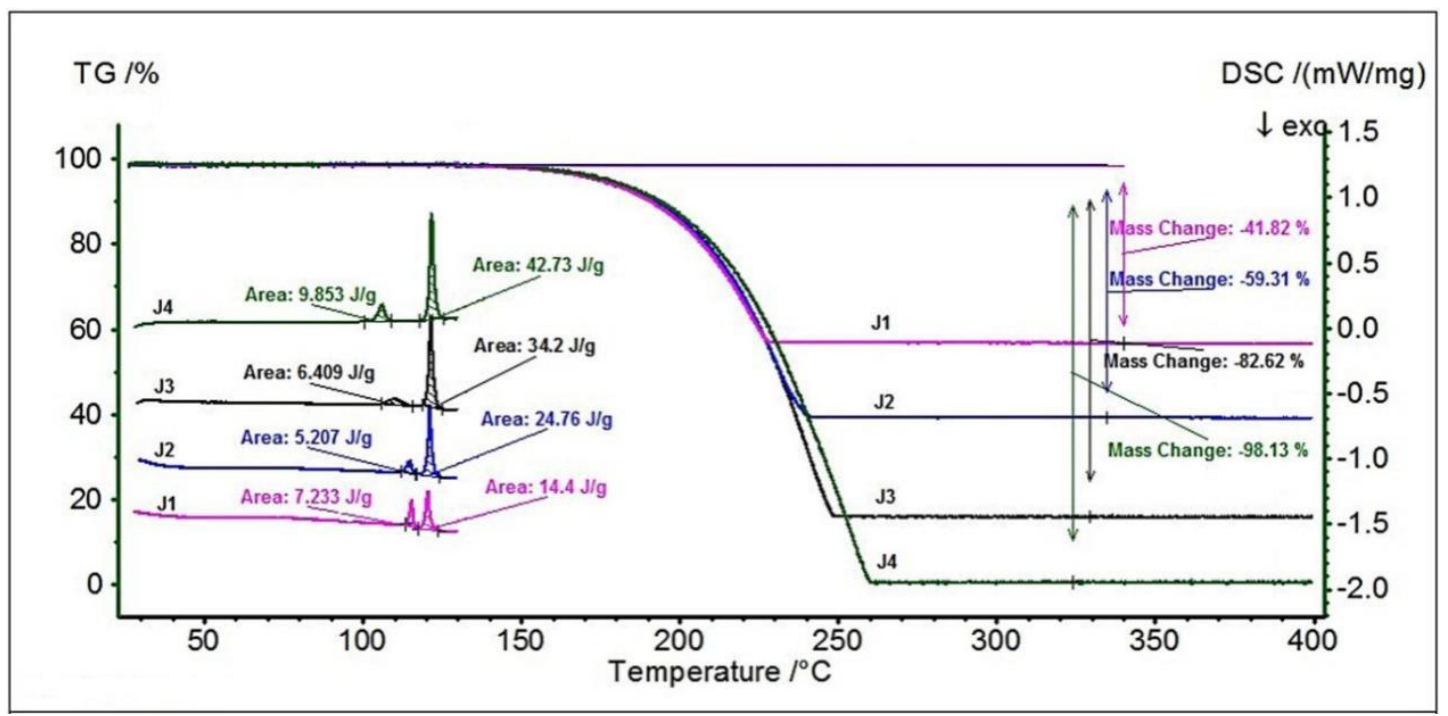

Figure 6. Melting enthalpy of $\beta$-sulfur for synthetic samples with various sulfur contents. 
Table 3. Correspondence between TGA and DSC data.

\begin{tabular}{ccc}
\hline \multirow{2}{*}{ Sample } & Mass loss by TGA $(\%)$ & $\begin{array}{c}\text { Melting enthalpy of } \boldsymbol{\beta} \text {-sulfur } \\
\left(\triangle \mathbf{H}, \mathbf{J} / \mathbf{g}^{*}\right)\end{array}$ \\
\hline J1 & 41.82 & 14.40 \\
J2 & 59.31 & 24.76 \\
J3 & 82.62 & 34.20 \\
J4 & 98.13 & 42.73 \\
\hline
\end{tabular}

*Note: The value is based on the Joules per gram of residue.

292 Based on the melting enthalpy of elemental sulfur, the quantification of sulfur can be 293 performed from STA measurements. In the above analysis, the second peak during the $1^{\text {st }}$ stage 294 was assumed to be caused by the melting of $\beta$-sulfur, both for the synthetic samples and the leach 295 residue. Additionally, the melting of $\beta$-sulfur occurs at a stable temperature around $120{ }^{\circ} \mathrm{C}$, 296 suggesting that no other changes affect the melting enthalpy of $\beta$-sulfur. Thus, the melting of $\beta$ 297 sulfur is used for the quantification of sulfur. The related function is calculated from a plot of 298 sulfur melting enthalpy versus mass change, based on the DSC and TGA data in Table 3. The 299 linear function-fitting plot is shown in Figure 7, with the equation interpreted as follows:

$$
\Delta H=0.4364 x-1.3858\left(\mathrm{R}^{2}=0.9882\right)
$$

Here, the variable $x$ refers to the percentage of elemental sulfur mass lost; $\mathrm{R}^{2}$ refers to the coefficient of determination. Based on this equation, the sulfur content can be easily determined as 303 long as the melting enthalpy is supplied. 


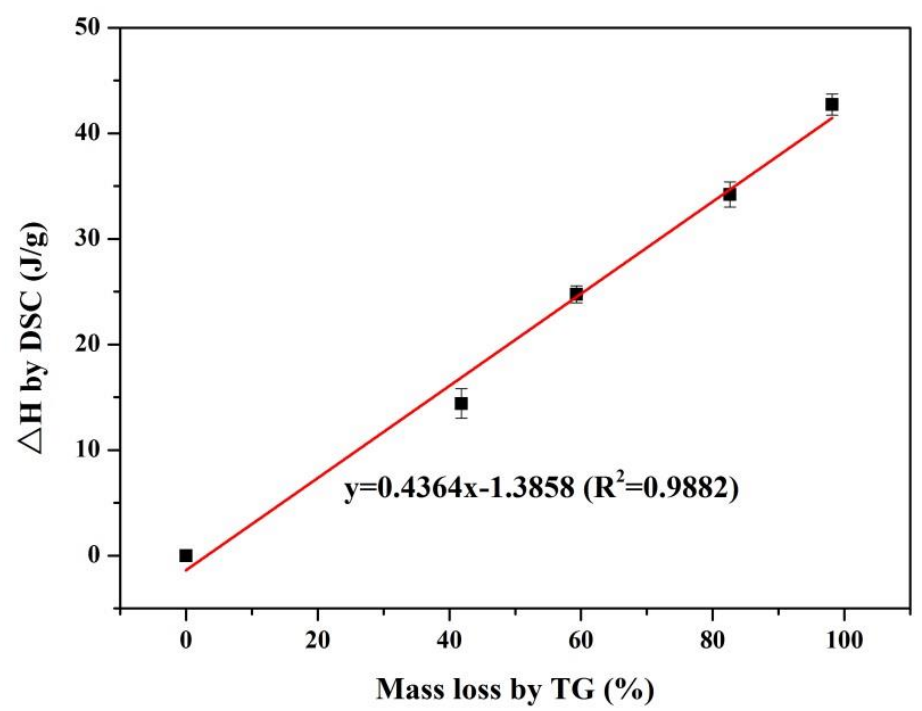

Figure 7. The linear fitting of TGA-based mass loss and DSC-based enthalpy.

\subsection{STA of leach residue with different sample masses}

To determine the influence of sample mass on the STA measurement, various sample masses were analyzed with a heating rate of $2{ }^{\circ} \mathrm{C} / \mathrm{min}$. The results are shown in Figure 8 and Table 4 .

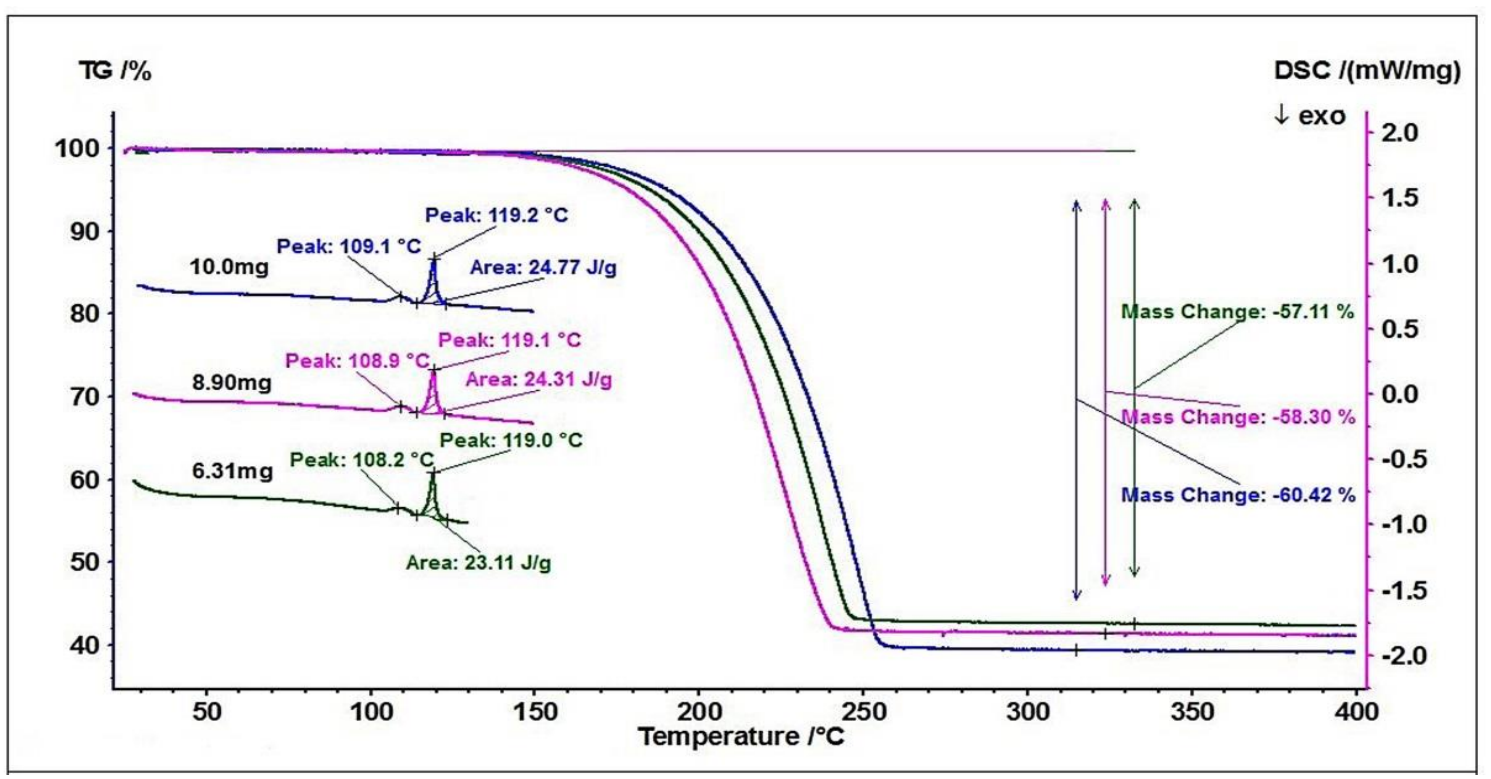

Figure 8. STA of the leach residue with various sample masses. 
As evidenced by TGA, the mass losses from the leach residue with samples masses of 6.31

$313 \mathrm{mg}, 8.90 \mathrm{mg}$ and $10.00 \mathrm{mg}$ were $57.11 \%, 58.30 \%$ and $60.42 \%$, respectively, with an average mass 314 loss of $58.61 \%$. In the DSC curve, the curve shape is similar for the samples with various masses. 315 The two endothermic peaks at around $108.6{ }^{\circ} \mathrm{C}$ and $119.1{ }^{\circ} \mathrm{C}$ are in agreement with the 316 transformation of $\alpha$-sulfur to $\beta$-sulfur and the melting of $\beta$-sulfur, respectively. The melting 317 enthalpy (marked as area under the curves in Figure 8) of $\beta$-sulfur below $150{ }^{\circ} \mathrm{C}$ (when there is no 318 mass loss) was used to calculate the percentage of sulfur in the residue by referring to the function 319 in Eq. 5. The calculation results are shown in Table 4.

320 It was observed that the TGA-based sulfur content (average 58.61\%) is in accordance with 321 DSC-based sulfur content (average 58.32\%), illustrating the reliability of STA quantification 322 methods. There is a slight increase of sulfur content with the increase of sample mass, as shown in 323 Table 4. This can be explained by the existence of other components, such as chalcopyrite and 324 quartz, in the leach residue, which may have a negative effect on the endothermic change rate of elemental sulfur and lead to the difference of sulfur content values (also see Section 4.3).

Table 4. Sulfur percentage of leach residue with various sample masses.

\begin{tabular}{ccccc}
\hline $\begin{array}{c}\text { Sample } \\
\text { mass }(\mathbf{m g})\end{array}$ & $\begin{array}{c}\text { TGA-based sulfur } \\
\text { content }(\boldsymbol{\%})\end{array}$ & $\begin{array}{c}\text { Average by TGA } \\
(\boldsymbol{\%})\end{array}$ & $\begin{array}{c}\text { DSC-based sulfur } \\
\text { content }(\boldsymbol{\%})\end{array}$ & $\begin{array}{c}\text { Average by } \\
\text { DSC (\%) }\end{array}$ \\
\hline 6.31 & 57.11 & & 56.13 & \\
8.90 & 58.30 & $58.61 \pm 1.37$ & 58.88 & $58.32 \pm 1.60$ \\
10.00 & 60.42 & & 59.94 & \\
\hline
\end{tabular}

\subsection{STA of leach residue with different heating rate}

To determine the influence of heating rate on the STA measurement, the STA of leach residue

330 with a mass of $10.00 \mathrm{mg}$ was analyzed, as shown in Figure 9 and Table 5. 


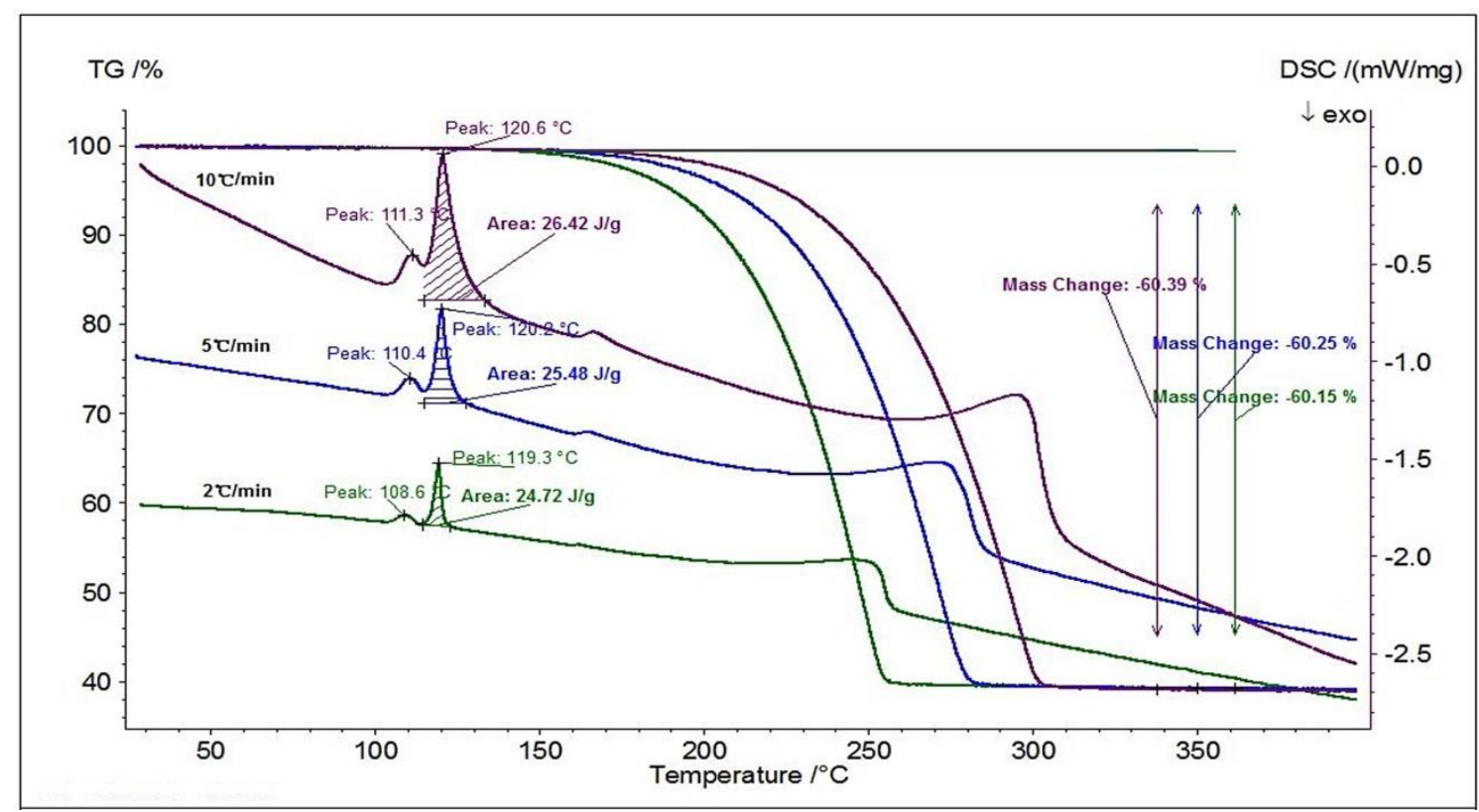

Figure 9. STA of leach residue with various heating rates.

Figure 9 shows the STA of the leach residue with different heating rates from $2{ }^{\circ} \mathrm{C} / \mathrm{min}$ to $10{ }^{\circ} \mathrm{C} / \mathrm{min}$. For the TGA curves, when the temperature is increased to above $150^{\circ} \mathrm{C}$, the mass begins to decrease. There is an average mass loss of $60.26 \%$ for the various heating rates of $2{ }^{\circ} \mathrm{C} / \mathrm{min}, 5{ }^{\circ} \mathrm{C} / \mathrm{min}$, and $10{ }^{\circ} \mathrm{C} / \mathrm{min}$, which is attributed to the volatilization of elemental sulfur. From the DSC curve data, the melting enthalpies were calculated to increase slightly from 24.72

Table 5. Sulfur percentage of leach residue with various heating rates.

\begin{tabular}{ccccc}
\hline $\begin{array}{c}\text { Heating rate } \\
\left({ }^{\circ} \mathbf{C} / \mathbf{m i n}\right)\end{array}$ & $\begin{array}{c}\text { TGA-based sulfur } \\
\text { content }(\boldsymbol{\%})\end{array}$ & $\begin{array}{c}\text { Average by } \\
\text { TGA }(\boldsymbol{\%})\end{array}$ & $\begin{array}{c}\text { DSC-based sulfur } \\
\text { content }(\boldsymbol{\%})\end{array}$ & $\begin{array}{c}\text { Average by } \\
\text { DSC (\%) }\end{array}$ \\
\hline 2 & 60.15 & & 59.82 & \\
5 & 60.25 & $60.26 \pm 0.10$ & 61.56 & $61.70 \pm 1.59$ \\
10 & 60.39 & & 63.72 & \\
\hline
\end{tabular}




\subsection{The analysis of STA-treated ash}

After the leach residue was treated by STA with a sample mass of $10.00 \mathrm{mg}$ and heating rate of

$2{ }^{\circ} \mathrm{C} / \mathrm{min}$, the ash was collected and subjected to XRD analysis. From the XRD data, it can be seen that the remaining components are quartz, chalcopyrite, pyrite, and muscovite. The elemental sulfur level was below detection limit, confirming that evaporation of elemental sulfur was complete.

353 According to semi-quantitative analysis of XRD, the amount of chalcopyrite is greater than $45 \%$, 354 indicating that the leach residue could be recycled to recover the chalcopyrite.

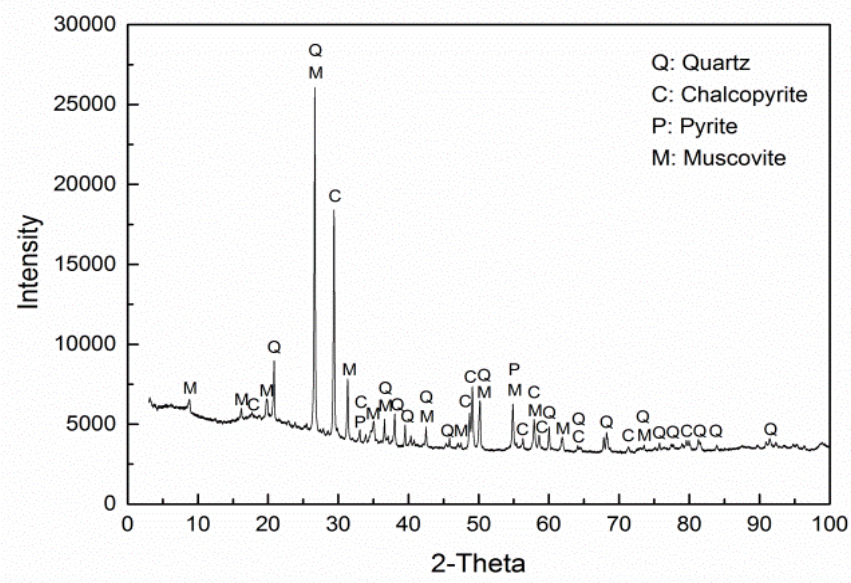

355

\begin{tabular}{ccccccc}
\hline Group & $\begin{array}{c}\text { Initial sample } \\
\text { mass (g) }\end{array}$ & $\begin{array}{c}\text { Volume of } \\
\text { toluene }(\mathbf{m L})\end{array}$ & $\begin{array}{c}\text { Time } \\
(\mathbf{m i n})\end{array}$ & $\begin{array}{c}\text { Residual } \\
\text { sample mass }(\mathbf{g})\end{array}$ & $\begin{array}{c}\text { Sulfur } \\
\text { content } \\
(\boldsymbol{\%})\end{array}$ & $\begin{array}{c}\text { Average } \\
\text { sulfur content } \\
(\boldsymbol{\%})\end{array}$ \\
\hline $\mathbf{1}$ & 3.00230 & 150 & 15 & 1.16701 & 61.13 & \\
$\mathbf{2}$ & 3.00150 & 150 & 20 & 1.17369 & 60.90 & \\
$\mathbf{3}$ & 3.00091 & 200 & 15 & 1.16348 & 61.23 & \\
$\mathbf{4}$ & 2.86188 & 150 & 20 & 1.10800 & 61.28 & \\
\hline
\end{tabular}

Figure 10. X-ray diffraction pattern of STA-treated ash.

\subsection{Validation by toluene extraction}

After extraction of sulfur by toluene for 15 to 20 minutes, it was assumed that the elemental sulfur was completely dissolved in toluene. The results are shown in Table 6. The toluene extraction of elemental sulfur confirms that the elemental sulfur content in the leach residue is $61.14 \pm 0.15 \%$.

Table 6. Extraction of sulfur from leach residue by toluene. 
As comparison with the result of toluene extraction, the sulfur content determined by DSC and TGA methods (using $10.00 \mathrm{mg}$ sample and $2{ }^{\circ} \mathrm{C} / \mathrm{min}$ heating rate), both of which are around $60 \%$, 366 is consistent with $61.14 \%$, indicating the usage of STA as a promising method for the qualitative and quantitative characterization of leach residues. DSC can also be used to determine the enthalpy change of the sample, giving information on the element allotropes and thermal changes of elemental sulfur. The TGA measurement is comparatively stable and accurate for the samples tested. Thus, STA provides a comprehensive method for samples of the kind investigated in this study.

\section{Conclusions}

In this work, an STA-based method for quantification and thermal characterization of the sulfur in the residue from a chalcopyrite leaching process was developed and evaluated. It was found that STA, which refers to the simultaneous application of thermogravimetric analysis (TGA) and differential scanning calorimetry (DSC) in a single instrument, can be conveniently used for the quantification and thermal characterization of sulfur in leach residues from the FLSmidth ${ }^{\circledR}$ ROL process.

The STA-based method on pure mineral assemblages using a known content of sulfur was used to establish the function to estimate sulfur content and verify the reliability of the method. The sulfur percentage was readily calculated from the sulfur melting enthalpy and mass loss.

For the leach residue sample, the only volatile component was elemental sulfur, which was readily evaporated in $\mathrm{N}_{2}$ at $400{ }^{\circ} \mathrm{C}$. A TGA-determined mass loss of around $60 \%$ for the leach residue was dominated by the evaporation of sulfur. Endothermic peaks at around $112^{\circ} \mathrm{C}$ in the DSC curve suggest that there is a sulfur phase change from $\alpha$-sulfur to $\beta$-sulfur, which melts at around $120{ }^{\circ} \mathrm{C}$. Furthermore, DSC not only indicates the sulfur phase changes, but it also allows the percentage of each phase to be calculated. Taking advantage of the enthalpy changes in DSC and the corresponding mass loss in TGA, the amount of elemental sulfur present in the sample can be 388 determined from a pre-established linear function. The results that were verified by toluene extraction show there is a good consistency with both the DSC sulfur quantification method and the TGA quantification. In summary, STA is recommended as a comprehensive quantification and characterization method for chalcopyrite leach residues containing elemental sulfur. 


\section{Acknowledgements}

This work is part of the Joint Doctoral Programme from the Sino-Danish Center for Education and Research (SDC). The work is also part of the advanced technology platform, Minerals and Cement Process Technology - MiCeTech, funded by the Innovation Fund Denmark, FLSmidth A/S, Hempel, and the Technical University of Denmark (Grant No. 39-2013-2). The financial and material supports of the work by the SDC and FLSmidth ${ }^{\circledR}$ Company are gratefully appreciated.

\section{References}

Berezowsky, R., Trytten, L., 2002. Commercialization of the acid pressure leaching of chalcopyrite. ALTA 2002, Copper 7 Forum, Perth, 40.

Braithwaite, J.W., Wadsworth, M.E., 1976. Oxidation of chalcopyrite under simulated conditions of deep solution mining. Edited by Yannopoulos, J.C. and Agarwal, J.C. Extractive Metallurgy of Copper, AIME, 2, 752-775.

Chaiko, D., Baczek, F., Rocks, S., Walters, T., Klepper, R., 2015a. The FLS Rapid Oxidative Leach (ROL) Process. Part I: Mechano-Chemical Process for Treating Chalcopyrite. Conference of Metallurgists, Toronto, Canada, 1-11.

Chaiko, D., Rocks, S., Walters, T., Asihene, S., Eyzaguirre, C., Klepper, R., Baczek, F., McMahon, G., 2015b. The FLS rapid oxidative leach (ROL) process. Part II: a new chemical activation process for chalcopyrite. Conference of Metallurgists, Toronto, Canada, 1-15.

Chiu, J., 1963. Visual observation in differential thermal analysis. Analytical Chemistry, 35(7), 933-934.

Córdoba, E.M., Muñoz, J.A., Blázquez M.L., González, F., Ballester, A., 2008. Leaching of chalcopyrite with ferric ion. Part I: General aspects. Hydrometallurgy, 93(3), 81-87.

Córdoba, E.M., Muñoz, J.A., Blázquez, M.L., González, F., Ballester, A., 2009. Passivation of chalcopyrite during its chemical leaching with ferric ion at $68{ }^{\circ} \mathrm{C}$. Minerals Engineering, 22(3), 229-235.

Crundwell, F.K., 2015. The semiconductor mechanism of dissolution and the pseudo-passivation of chalcopyrite. Canadian Metallurgical Quarterly, 1(3), 1-10.

Currell, B.R., Williams, A.J., 1974. Thermal analysis of elemental sulphur. Thermochimica Acta, 9(3), 255-259.

Donohue, J., 1974. Structures of the Elements. Wiley, New York, 324. 
Dutrizac, J.E., MacDonald, R.J.C., 1974. Ferric ion as a leaching medium. Minerals Science Engineering, 6, 59-100.

Eyzaguirre, C., Rocks, S., Klepper, R., Baczek, F.A., Chaiko, D., 2015. The FLSmidth ${ }^{\circledR}$ rapid oxidative leach (ROL) process: a mechano-chemical approach for rapid metal sulfide. The $7^{\text {th }}$ International Seminar on Process Hydrometallurgy.Hydroprocess, 1-11.

Ficara, M.L.G., Moreira, E., 1988. Utilization of differential scanning calorimetry technique for determination of high sulfur content. Thermochimica Acta, 134(4), 435-440.

Ghahremaninezhad, A., Asselin, E., Dixon, D.G., 2010. Electrochemical evaluation of the surface of chalcopyrite during dissolution in sulfuric acid solution. Electrochimica Acta, 55(18), 50415056.

Ghahremaninezhad, A., Dixon, D.G., Asselin, E., 2012. Kinetics of the ferric-ferrous couple on anodically passivated chalcopyrite $\left(\mathrm{CuFeS}_{2}\right)$ electrodes. Hydrometallurgy, 125-126, 42-49.

Gill P., Moghadam T.T., Ranjbar B., 2010. Differential scanning calorimetry techniques: applications in biology and nanoscience. Journal of Biomolecular Techniques, 21(4), 167-193

Gómez, C., Figueroa, M., Muñoz, J.A., Blázquez, M.L., Ballester, A., 1996. Electrochemistry of chalcopyrite. Hydrometallurgy, 43, 331-344.

Havlik, T., Kammel, R., 1995. Leaching of chalcopyrite with acidified ferric chloride and carbon tetrachloride addition. Minerals Engineering, 8, 1125-1134.

Hemingway, B.S., 1999. Heat capacity and thermodynamic properties of equilibrium sulfur to the temperature $388.36 \mathrm{~K}$, and the heat capacity of calorimetry conference copper. U.S. Geological Survey Open-File Report, 99-324.

Jay, S., Cézac, P., Serin, J. P., Contamine, F., Martin, C., Mercadier, J., 2009. Solubility of elemental sulfur in toluene between (267.15 and 313.15) K under atmospheric pressure. Journal of Chemical \& Engineering, 54(12), 3238-3241.

Javier, V., Yamada, R., Inoue, C. 2009. Effect of $\mathrm{pH}$ reduction and ferric ion addition on the leaching of chalcopyrite at thermophilic temperatures. Hydrometallurgy, 96(1), 62-71.

Karcz, A.P., Damø, A.J., Illerup, J.B., Rocks, S., Dam-Johansen, K., Chaiko, D., 2017. Electron microscope investigations of activated chalcopyrite particles via the FLSmidth ${ }^{\circledR}$ ROL process. Journal of Materials Science, 52(20), 1-10.

Klauber, C., 2008. A critical review of the surface chemistry of acidic ferric sulphate dissolution of chalcopyrite with regards to hindered dissolution. International Journal of Mineral Processing, $86(1), 1-17$ 
Koningsberger, D.C., De Neef, T., 1972. New method in calculating the polymerization parameters of liquid sulphur and selenium. Chemical Physics Letters, 14(4), 453-454.

Laitinen, R., Niinisto, L., 1978. Thermal behavior of the monoclinic allotropes $\gamma$-sulfur and $\alpha$ selenium and some structurally related sulfur-selenium compounds. Journal of thermal analysis, $13,99-104$.

Majima, H., Awakura, Y., Hirato, T., Tanaka, T., 1985. The leaching of chalcopyrite in ferric chloride and ferric sulfate solutions. Canadian Metallurgical Quarterly, 24(4), 283-291.

McDonald, R.G., Muir, D.M., 2007. Pressure oxidation leaching of chalcopyrite Part I: comparison of high and low temperature reaction kinetics and products. Hydrometallurgy, 86, 191-205.

Meyer, B., 1964. Solid allotropes of sulfur. Chemical Reviews, 64(4), 429-451.

Meyer, B., 1976. Elemental sulfur. Chemical Reviews, 76(3), 367-388.

Meyer, B., Austin, J.M., Jensen, D., 1971. Solubility of sulfur in liquid sulfur dioxide, carbon disulfide, and carbon tetrachloride. Journal of Chemical \& Engineering Data, 16(3), 159-160.

Miller, G.W., 1971. Thermal analysis of polymers. VIII. Dilatometric and thermal optical behavior of sulfur. Journal of Applied Polymer Science, 15(8), 1985-1994.

Munther, A., Wu, H., Glarborg, P., 2010. Thermogravimetric analysis of combustible waste components. Radiation Physics \& Chemistry, 45(5), 691-693.

Nazari, G., Dixon, D.G., Dreisinger, D.B., 2012. The role of silver-enhanced pyrite in enhancing the electrical conductivity of sulfur product layer during chalcopyrite leaching in the galvanox ${ }^{\mathrm{TM}}$ process. Hydrometallurgy, 113-114, 177-184.

Olvera, O.G., Rebolledo, M., Asselin, E., 2016. Atmospheric ferric sulfate leaching of chalcopyrite: thermodynamics, kinetics and electrochemistry. Hydrometallurgy, 165, 148-158.

Osseo-Asare, K., 1992. Semiconductor electrochemistry and hydrometallurgical dissolution processes. Hydrometallurgy, 29(92), 61-90.

Perrenot, B., Widmann, G., 1994. Polymorphism by differential scanning calorimetry. Thermochimica Acta, 234, 31-39.

Pradhan, N., Nathsarma, K.C., Rao, K.S., Sukla, L.B., Mishra, B.K., 2008. Heap bioleaching of chalcopyrite: a review. Minerals Engineering, 21(5), 355-365.

Rivera-Vasquez, B.F., Dixon, D., 2015. Rapid atmospheric leaching of enargite in acidic ferric sulfate media. Hydrometallurgy 152, 149-158.

Sahu, S.K., Asselin, E., 2011. Characterization of residue generated during medium temperature leaching of chalcopyrite concentrate under CESL conditions. Hydrometallurgy, 110(1), 107-114. 
Sands, D.E., 1965. The crystal structure of monoclinic $(\beta)$ sulfur. Journal of the American Chemical Society, 87(6), 1395-1396.

Sciamanna, S.F., Lynn, S., 1988. Sulfur solubility in pure and mixed organic solvents. Industrial \& Engineering Chemistry Research, 27(3), 485-491.

Steudel, R., Eckert, B., 2003. Solid sulfur allotropes. Springer Berlin Heidelberg, 230, 1-80.

Steudel R., Passlack-Stephan S., Holdt G., 1984.Thermal polymerization and depolymerization reactions of 10 sulfur allotropes studied by HPLC and DSC. Zeitschrift Für Anorganische Und Allgemeine Chemie, 517(10), 7-42.

Thackray, M., 1970. Melting point intervals of sulfur allotropes. Journal of Chemical \& Engineering Data, 15(4), 495-497.

Wan, R.Y., Miller, J.D., Foley, J., Pons, S., 1984. Electrochemical features of the ferric sulfate leaching of $\mathrm{CuFeS}_{2} / \mathrm{C}$ aggregates. In Proceedings-The Electrochemical Society, 84-10, 391-416.

Wang, J., Gan, X., Zhao, H., Hu, M., Li, K., Qin, W., Qiu, G., 2016. Dissolution and passivation mechanisms of chalcopyrite during bioleaching: DFT calculation, XPS and electrochemistry analysis. Minerals Engineering, 98, 264-278. 